\title{
Analysis of Supporting and Increasing Factors in Improving the Political Participation of Communities through the e-Voting System in Selecting the Village Head Selection in Pemalang District 2018
}

\author{
Lusia Astrika $^{1}$, Neny Marlina ${ }^{2}$ \\ \{lusia.astrika@gmail.com ${ }^{1}$ \} \\ Universitas Diponegoro, Indonesia ${ }^{1,2}$
}

\begin{abstract}
This study aimed to analyze the supporting and inhibiting factors in increasing public political participation with the e-voting system in the simultaneous village head election in the Regency Pemalang in 2018. The election of village heads (Pilkades) was carried out simultaneously but gradually in 172 villages held from 2 September to 4 November 2018. This study uses a qualitative method, which seeks and obtains information in depth and as broadly as possible about the supporting factors and obstacles to increasing community participation through the e-voting system in the simultaneous village head election in Pemalang District in 2018. The informants in this study were selected with a purposive sampling technique, which involves the Office of Community Empowerment and Village Government (Dinpermasdes) of Pemalang Regency, the Head of the Government of Pemalang Regency, the Pemalang District Election Committee, and the voting community. Based on research that has been done, a supporting factor in increasing public participation through e-voting is good coordination between institutions especially at the district level, starting from the socialization stage to the election stage. The factor that supports increasing public participation through evoting is the emergence of curiosity and a great curiosity in the voting community itself. The inhibiting factor in increasing community participation through e-voting is the lack of understanding and coordination at the village level, especially at the socialization stage. The second limiting factor is the problem of lack of facilities. Seeing the supporting and inhibiting factors in increasing community participation through e-voting in the village head election in Pemalang District in 2018, it is recommended to improve coordination at the village level, especially at the socialization stage, improve existing facilities, and provide socialization and motivation to the community of the benefits gained by the e-voting system.
\end{abstract}

Keywords: Participation, e-Voting, Pilkades, Pemalang Regency.

\section{Introduction}

The village holds an important role in national development because the village has made a major contribution in creating national stability. In village development the purpose is to carry out development for the village community. Village community development is an important and decisive component. Therefore, this component must be built in full together with the physical environment and social environment. This makes village development 
complex because it involves the community as the center of development [1]. Village community participation is manifested in the form of directing and utilizing existing resources and funds in the community to increase development activities in rural areas so that the success of development in the community is not always determined by the availability of financial resources and financial management but is more influenced by community participation and response to development or can be called community participation. One of the fundamental problems in the process of implementing village governance is how to build or create government mechanisms that can carry out its mission in realizing a prosperous society in a just manner. The government must carry out development based on the aspirations of the people, and provide the best public services. In the case of development based on community aspirations, electing the village head as the head of the village government organization is no less important to discuss. This is because choosing the village head is the first step in determining the right leader in the village development process.

Law Number 6 of 2014 concerning Villages provides different procedures for holding village head elections [2]. If initially the village head election was conducted with different time periods between villages, now the village head election process is held simultaneously in one district.

The election of village heads (Pilkades) simultaneously becomes an interesting phenomenon in rural political studies because the election at the village level becomes noisier when it is held simultaneously. One of the simultaneous elections for village heads (Pilkades) to observe is in Pemalang District in 2018. The implementation of the village heads (Pilkades) using the e-Voting system in Pemalang District, is the third activity in 2018, after Sidoarjo Regency and Jambi Regency, however the implementation of the village heads (Pilkades) with the e-Voting system in Pemalang Regency, was the first implementation using fingerprints. The election of the village heads (Pilkades) was carried out simultaneously but gradually in 172 villages. The election of village heads (Pilkades) held simultaneously from September 2 to November 4, 2018 through this e-voting system is considered more efficient and easier for all levels of society who already have an electronic identity card (e-KTP) [3].Through this Evoting system, it is a new mechanism in the implementation of the village heads (Pilkades), especially when considering the conditions in the villages, this system is interesting to be seen as a form of innovation. Because this mechanism is new, of course there are factors that support or hinder the operation of this system. This study aims to analyze the supporting and inhibiting factors in increasing public political participation with the e-voting system in the simultaneous village head elections in Pemalang District in 2018.

\section{Literature Review}

\subsection{Political Participation}

Political participation is the activity of a person or group of people to participate actively in political life, namely by choosing the leader of the state and directly or indirectly, influencing government policy [4]. According to Surbakti [5] political participation is divided into two namely active participation and passive participation. Active participation is to propose a general policy, propose alternative public policies that are different from the policies made by the government, submit criticisms and improvements to straighten out policies, pay taxes and elect government leaders. Conversely, activities that fall into the 
category of passive participation in the form of activities that obey the government, accept, and carry out any government decision.

According to Myron Weiner, as quoted by Mas'oed [6], there are at least five things that led to the movement towards wider participation in the political process.

a) Modernization

When urban dwellers (i.e. workers, traders, and professionals) commercialize agriculture, industrialization, increased urbanization, dissemination of literacy, improved education and mass media development, they feel they can influence their own destiny, increasingly demanding more participation in power political.

b) Structural Changes in Social Classes

Once a new working class and middle class are formed which are widespread and changing during the process of industrialization and modernization, the issue of who has the right to participate in political decision making becomes important and results in changes in the pattern of political participation.

c) Influence of Intellectuals and Modern Mass Communication

Intellectuals (scholars, philosophers, authors, journalists) often express ideas such as egalisterism and nationalism to the public to raise the demand for broad mass participation in political decision making. Modern transportation and communication systems facilitate and accelerate the spread of new ideas.

d) Conflicts between Groups of Political Leaders

If competition arises for power, the strategy usually used by opposing groups is to seek support from the people. In this case they certainly consider it legitimate and fight for ideas of mass participation and consequently create movements that demand that these "rights" be fulfilled. So, the middle class in its struggle against the workers and help expand people's suffrage.

e) Widespread Government Involvement in Social, Economic and Cultural Affairs Expanding government activities in new policy areas usually means that the consequences of government actions become increasingly pervasive in people's daily lives. Without legal rights to political participation, individuals are truly powerless to face the government and can easily be influenced by government actions that may be detrimental to their interests. Therefore, the broad scope of government activity often stimulates the emergence of organized demands to participate in political decisionmaking.

Martin Harrop and William Miller argue that the voter behavior approach in political science is divided into three broad outlines of the approach/model. First, a very psychological approach called party identification. Second, the approach that considers the individual has a rational capacity to determine his choices (rational choice). Voters are considered to understand, why they choose, what is the impact of their choices and are they aware that the choices made are important instruments for the articulation of their political interests. Then the third approach, is a sociological approach (sociological approach). Where this approach emphasizes on groups and parties, instead of individual voters.

\subsection{Election of Village Head}

Regulation Number 6 of 2014 Article 31 stipulates that the election of village heads shall be held simultaneously throughout the regency/city area. District/city regional governments determine the policy of implementing village head elections simultaneously with district/city regional regulations. Then in Article 40 Government Regulation Number 43 of 2014 
concerning Regulations for Implementing Law Number 6 of 2014 concerning Villages, it is determined that simultaneous village head elections can be held at most 3 (three) times within a period of 6 (six) years [2]. In the event of a vacancy of the village head's position in the holding of simultaneous village head elections, the district head/mayor appoints the acting village head. Acting village chiefs come from civil servants within the district/city government.

Election of Village Heads is carried out simultaneously through several stages, which are mentioned in article 6 of domestic minister regulations (Permendagri) Number 112 of 2014 concerning election of village heads, mentioning the implementation of village head elections through the stages of preparation, nomination, voting and determination. Before the village head is elected, the village consultative body notifies the village head of the term of office of the village chief in writing 6 (six) months before the end of the term of office. The village consultative body formed the village head election committee. The village head election committee is independent and impartial. The village head election committee consists of elements of the village apparatus, social institutions, and village community leaders. The village head is elected directly by and from the villagers of a citizen of the Republic of Indonesia who meets the requirements with a term of office of 6 (six) years from the date of inauguration. The village head can hold a maximum of 3 (three) consecutive terms of office or not in a row. The requirements for candidates for village head candidates as specified in article 33 of Law number 6 of 2014 as follows [2]:

a) Citizens of the Republic of Indonesia;

b) Fear God Almighty;

c) Upholding and practicing Pancasila, implementing the 1945 constitution of the Republic of Indonesia, and maintaining and maintaining the integrity of the Unitary State of the Republic of Indonesia and Unity in Diversity;

d) The lowest educated graduate of junior high school or equivalent;

e) The lowest age is 25 (twenty-five) years when registering;

f) Willing to be nominated as village head;

g) Registered as a resident and residing in the local village at least 1 (one) year before registration;

h) Not serving a prison sentence;

i) Never been sentenced to imprisonment based on a court decision that has permanent legal force for committing a prison sentence of at least 5 (five) years or more, except 5 (five) years after finishing serving a prison sentence and announcing honestly and openly to the public that those who concerned has been convicted and not as a perpetrator of recurrent crimes;

j) Not being revoked of his right to vote in accordance with a court decision that has permanent legal force;

k) Healthy body;

1) Never as Village Head for 3 (three) term of office; and

m) Other requirements stipulated in the regional regulation.

The procedure for electing village heads as regulated in Law Number 6 of 2014 [2] on villages namely that the mechanism for organizing village head elections is carried out by the election committee, the cost of electing village heads is borne by the regional revenue and expenditures budget $(A P B D)$. The election of village heads is carried out through the stages of selecting and screening prospective candidates, determining candidates, campaigns, voting, and determining the elected candidates. Candidates for the village head are elected based on the vote acquisition. The candidate for the elected village head above is then submitted by the 
head of the election committee to the village consultative body (BPD) no later than seven days after the appointment of the elected village head candidate, then the village consultative body (BPD) no later than seven days after receiving the report. The regent/mayor shall issue a decision of the regent/mayor regarding the endorsement of the elected village head candidate no later than thirty working days from the date of receipt of the election results from the election committee in the form of a regent/mayor decision. The elected village head is appointed by the regent/mayor or appointed official no later than 30 working days from the date of issuance of the regent/mayor's decision.

\section{3 e-Voting System}

Electronic voting refers to the use of information technology in the voting. The e-Voting system at the time of the election is used to overcome data manipulation. More about the application of e-voting and e-verification of voters, the head of the electronic election program (BPPT) Andrari Grahitandaru explained, how to vote with the voting method, the following explanation (Okezone newspaper on September 30, 2019):

a) Voters must bring their identity card $(K T P)$ verified with identity card $(K T P)$ readers to ensure compatibility of the identity card $(K T P)$ data with voters.

b) After the data is matched, the e-verification system automatically states the presence if the name is in the permanent constituency $(D P T)$, or the system refuses if the voter is not in the permanent constituency $(D P T)$. This e-verification system also functions as a record of attendance / attendance of voters or Form C7 in elections.

c) If you pass the voter e-verification, the voter is given a v-token. This card functions as an e-voting device to activate.

d) The v-token is then inserted into the smartcard reader so that it displays one electronic ballot.

e) Voters can vote by touching the picture / number of one of the candidates. The system will give a 'YES' or 'NO' notification to the selected option. If you are sure, the voter must press 'YES'. At this stage, the voter can touch the 'NO' option if you want to change the choice.

f) After making a choice, the printer prints an audit receipt and the picker picks up the receipt paper in the form of barcode paper. This is proof that voters have voted.

g) The receipt paper is then put into the audit box. It functions as a comparison data if there is a dispute over the number of voters who vote.

Concurrent e-voting conducted in Pemalang Regency uses a set of tools consisting of five tools, which are as follows:

a) A special computer is used to display the permanent voter list, the inputted permanent constituency (DPT) is verified data and is obtained from the village head election (Pilkades) committee.

b) Identity card reader (KTP Reader). Its function is to read population data that wants to fulfill its voting rights.

c) Computer generator, which activates the voter access system to the voting booth.

d) Smart Card as opening access.

e) Thermal Printer, this device uses the village head election (Pilkades) application and other digital codes.

The e-Voting system is actually the same as a conventional system, the difference is only in the results that can be directly recognized using a machine. Voters still choose the conventional system, but the difference is directly choosing the layer. So, this system does not 
use internet networks. Given that the internet network in the village is not as smooth as in the city environment. Following the electoral explanation chart with the e-Voting system on the Chart 1 .

Chart 1. Election With E-Voting

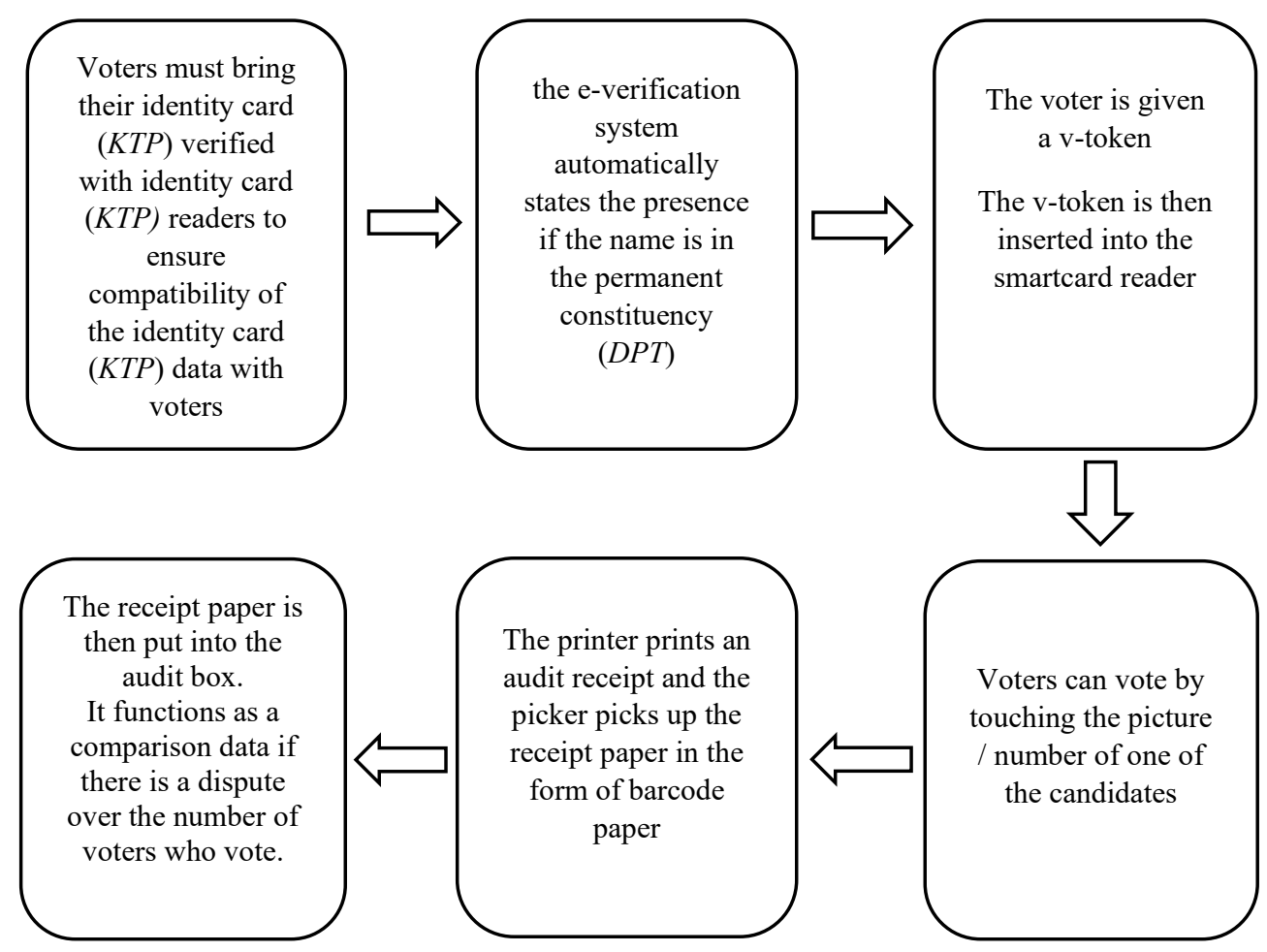

Source: Data processed, 2019.

\subsection{Research Methods}

This study uses a qualitative method, which seeks and obtains information in depth and as broadly as possible about the supporting and inhibiting factors of increasing community participation through the e-voting system in the simultaneous village head election in Pemalang District in 2018. The informants in this study were selected with a purposive sampling technique, which involves the Office of Community Empowerment and Village Government (Dinpermasdes) of Pemalang Regency, the Head of the Government of Pemalang Regency, the Pemalang District Election Committee, and the voting community. Data collection techniques used in this study were in-depth interviews (in-depth interviews), documentation, book study, and observation. Data analysis techniques in this study are data reduction, data display, and drawing conclusions [7][8]. 


\section{Discussion}

\subsection{Supporting Factors in Increasing Participation of Pemalang Regency Communities in 2018 Simultaneous Election through e-Voting}

Simultaneous election in Pemalang District with the e-Voting system is quite interesting, to do, this is because in terms of vote counting with e-Voting can minimize the psychological impact caused as in manual elections. If the counting is done manually, the candidates and supporters will be tested for adrenaline, especially during the vote count, while with e-Voting, the psychological impact can be mitigated. e-Voting can minimize fraud compared to manual selection. In addition, the existence of e-voting is more stringent than the manual verification, this is because the basis of verification by e-Voting is the electronic identity card (e-KTP) whose data cannot be manipulated.

Based on the decree of the Pemalang Regent Number: 141.1/386/2018 Regarding the Implementation of the election of the Head of the Simultaneous village head in Pemalang District in 2018, which was set on May 7, 2018 by Pemalang Regent, H. Junaedi, SH, MM, the village head election (Pilkades) will be held gradually starting on Sunday September 2, September 9, September 16, September 23, September 30, October 7, October 14, October 21, October 28, and November 4. In its implementation, the village head election (Pilkades) simultaneously with e-Voting has supporting factors. The first factor is good coordination between institutions, especially at the district level, starting from the socialization stage to the election stage listed in the decree of the Pemalang Regent. Number 36 Year 2015 concerning procedures for election, appointment, and dismissal of village heads. This is because the election of the village head is a "Joint Work Commitment", so that each institution must be involved (the results of an interview with Bagus Sutopo as. head of village administration at the Dinpermades of Pemalang Regency on May 2, 2019). In the regent's decree number 36 Year 2015 article 10 states that "in order to support the smooth running of electronic voting (evoting), the regent forms a core technical team and field technical team to assist the election committee". In addition, article 12 states that "in carrying out their duties, the village supervisory team may request facilitation from the village government, village representative body (BPD), head of sub-district (Camat), Sub-district supervisory Team and the regent". As for what is meant by facilitation in the form of providing guidelines, explanations/information, briefing/direction and other facilitation needed.

The second factor besides the good coordination between institutions, the factor that supports increased public participation through e-voting is the emergence of curiosity and a great curiosity in the voting community itself. Voters who are curious and want to know how the election with e-voting will roll out to the polling station (TPS) to use their voting rights. Basically, they are curious about the tools and methods used in voting by e-voting. The villagers were so enthusiastic about participating in the elections simultaneously with this evoting, as evidenced by the queue snaking at the polling station when they were going to exercise their voting rights (interview with Sukandar as the head of Banjardawa Village on 30 July 2019). According to Sukandar, people who come from housing and classified as middle and upper economic status and high social status participated in voting by coming to the polling stations and willing to wait in line for a long time and are willing to heat up under the hot sun. 


\subsection{Inhibiting Factors in Increasing Participation of Pemalang Regency Communities in 2018 Simultaneous Election through e-Voting}

The simultaneous of village head election (Pilkades) in 2018 through E-voting in Pemalang District have several weaknesses, namely the tools used do not yet support people with disabilities. Ballots have not been made using braille and there is no pickup for those who have difficulty accessing the polling stations (TPS). This is different from manual voting, for persons with disabilities who have difficulty accessing polling stations, officers will come to the house or there will be a pickup from the officer. This tool factor is also a weakness of this system, especially for the elderly, this is because most of them do not have adequate knowledge about this technology when compared to young age (interview with Sukandar, Head of Banjardawa Village on 30 July 2019).

There is a lack of understanding and coordination at the village level, especially at the socialization stage. Some village committees have failed to understand the electoral procedure using the E-Voting system (the results of an interview with Bagus Sutopo as the Head of the Village Administration at the Dinpermades in Pemalang Regency on May 2, 2019). This results in a misinterpretation (multi-interpretation) because the messages received and practiced are different. The existence of multiple interpretations will influence the policies issued by the village committee, which in turn will lead to problems or conflicts. For example in handling broken e-voting machines, procuring tent facilities for outdoor voters, giving numbers to voters who come to polling stations, anticipating if voters come in large numbers at one time, lack of attention to elderly voters and those with disabilities, permanent constituency $(D P T)$ that is not recorded and has not been socialized (results of an interview with Fauxi as governance (Tapem) of Taman District, 30 July 2019).

Other inhibiting factors are the problem of lack of facilities, such as e-voting equipment which is damaged/error, the election place which is centered in one place only resulting in a surge in the number of voters at one time, the absence of tent facilities, the location of the election that is less strategic, and the time of the election that is not on schedule. Discomfort also occurs in these simultaneous Pilkades in several villages, one of them in Penggarit and Banjardawa villages), such as the absence of adequate seats to wait for the voting queue, the absence of queue numbers, the absence of spit so they must be willing to heat up, the location or a collection point that is only at one point, so the queue is snaking, the queue is long so that many decide to go home and not vote, there is no pickup even though access to the polling station is far and infrastructure is lacking, equipment is damaged/error resulting in time for voting back down and result in noise/conflict/jostling. This inconvenience caused the voting community to be reluctant to participate, even some of them wanted to re-elect the village head with a conventional system. As in Penggarit Village, most villagers want to go back to the manual method because it is felt that it is easier to access and does not eliminate habits in the village (interview with Imam as the Head of Penggarit Village, 30 July 2019).

In the simultaneous election with e-voting also raises problems or conflicts that lead to the emergence of a lawsuit to the administrative court, with a chronology that begins with the emergence of a sense of disagreement because of losing the vote counting process, then protesting to the selection committee, and because of disappointment and disagreement later filed a lawsuit to the administrative court. After being processed by law, it was proven that the selection committee was innocent and had followed the existing procedures. The plaintiffs felt that the e-voting that was carried out was fraudulent, they protested because when cheating pictures/photographs were lost, they were considered illegal (interview with Gustoro as Head of Penggarit Village Government, 30 July 2019). 


\section{Conclusions}

Each village basically has its own problems, because each village has its own distinctiveness/uniqueness. Supporting factors in the simultaneous of village head election (Pilkades) in Pemalang Regency in 2018 with this e-voting is a joint commitment of each related agency so that it will launch this activity and the emergence of curiosity from the village community thus increasing participation in the simultaneous of village head election (Pilkades). As for the inhibiting factors in the simultaneous of village head election (Pilkades) with e-voting are problems with error tools, lack of facilities, and lack of understanding / coordination, especially at the stage of socialization.

\subsection{Suggestions}

Seeing the supporting and inhibiting factors in increasing community participation through e-voting in the village head election in Pemalang District in 2018, it is suggested to improve coordination at the village level, especially at the socialization stage, improve existing facilities, especially during the elections, and provide socialization and motivation to the community of the benefits gained by the e-voting system, so that in the end the voting community can actively participate. Also maintain the local wisdom of the village community in relation to the voting process and method. Like for example holding a way of voting with the theme of village head election (Pilkades) tourism, namely voting that brings local wisdom of the local village community, for example by interspersed with snacks and marketing tourist attractions in the local village.

\section{References}

[1] T. Ardilah, "Upaya Kepala Desa Untuk Meningkatkan Partisipasi Masyarakat Dalam Pembangunan Desa (Studi di Desa Bareng Kecamatan Bareng Kabupaten Jombang)," J. Adm. Publik, vol. 2, no. 1, pp. 71-77, 2014.

[2] U.-U. Nomor, "tahun 2014 tentang Desa." 6AD.

[3] Suryono, "Pertama di Indonesia, 83 Kades Hasil E-Voting di Pemalang Dilantik," iNews. .

[4] M. Budiardjo, Dasar-dasar ilmu politik. Gramedia pustaka utama, 2003.

[5] R. Surbakti, "Memahami Ilmu Politik, Jakarta," PT Gramedia Widiasarana Indones., 2010.

[6] M. Mas'oed, "Studi Hubungan Internasional: Tingkat Analisis dan Teorisasi," Univ. Gadjah Mada, 1989.

[7] S. Sugiyono, "Research Method Quantitative and Qualitative R\&D," Alf. Bandung, 2010.

[8] S. Heribertus, "Metodologi Penelitian Kualitatif: Dasar Teori dan Terapannya Dalam Penelitian." Surakarta: UNS Press, 1998. 